\title{
Online Learning Evaluation During the Covid-19 Pandemic in Accounting Department of Polytechnic State Banjarmasin
}

\author{
Monika Handayani*, Muhammad Bahit, Muhammad Hendra Sunarya, Nadia Puteri Utami \\ Computerized Accounting Study Program \\ Banjarmasin State Polytechnic \\ Banjarmasin, Indonesia \\ Monika.handayani@poliban.ac.id*, bahit@poliban.ac.id, hendra@poliban.ac.id, Nadiaputeriutami@akuntansipoliban.ac.id
}

\begin{abstract}
The outbreak of the Corona Virus Disease 2019 (Covid-19) pandemic cases throughout the world has resulted in forcing countries affected by the Covid-19 pandemic to stop all activities related to the masses by issuing a physical distancing policy. This is done to reduce the spread of the Covid-19 pandemic which can be transmitted from various activities. This physical distancing policy requires all elements of the community to work from home (WFH). No exception to the world of education which also stopped the entire teaching and learning process which had been done face-to-face and had to change to face-to-face or online. However, the virtual learning process that is carried out without prior preparation results in various problems, both at the teacher and student level. As for the success of online learning, there is a need for rules and cooperation between lecturers and students and with policy makers in order to provide facilities that support online lectures. On the other hand, the success of online lectures during the COVID-19 crisis also depends on using the right online media to use. Therefore, this study aims to evaluate online learning in the Department of Accounting at Banjarmasin State Polytechnic. The analysis showed that the lectures online more like student/i based virtual learning environment (VLE) followed online meetings and group chat. In addition, this study also found that online learning at the Banjarmasin State Polytechnic Accounting Department during the Covid-19 pandemic had gone well.
\end{abstract}

Keywords-online learning, virtual learning, education and COVID-19

\section{INTRODUCTION}

The outbreak of the Corona Virus Disease 2019 (Covid19) pandemic that hit Wuhan, China since December 2019 and resulted in the spread in 217 countries worldwide as of May 28, 2020. Where positive cases have been confirmed worldwide $5,556,679$ people with the number of cases died 351,866 Javanese [1]. Meanwhile, positive confirmed cases in Indonesia reached 24,538 people with 6,240 cured cases and the number of confirmed positive cases was 1,486 people [2].

With the number of cases increasing day by day since it was announced in the city of Wuhan in December 2019, the best way to prevent and slow down the transmission of the COVID-19 virus is by washing hands with alcohol and not touching the face [3]. However, positive cases of COVID-19 continue to increase, forcing a number of countries to implement physical distancing policies in an effort to control the spread of the COVID-19 virus infection. The existence of the physical distancing policy resulted in various government, educational, tourism, industrial and private institutions being affected by this policy. In fact, all educational institutions from the kindergarten level to higher education institutions implement work from home (WFH).

The WFH policy is contained in the Decree of the Secretary General of the Ministry of Education and Culture Number 36603/A.A5/OT/2020 dated 15 March 2020 and the Letter of the Head of the HR Bureau of the Ministry of Education and Culture Number 36604/A3/KP/2020 dated 15 March. The policy was followed up by each related agency so that they could implement WFH policies during the COVID-19 pandemic, including the Banjarmasin State Polytechnic which also implemented WFH policies with director's decree No.614/PL18/KL/2020 dated March 16n2020 to prevent the spread. COVID-19 within the Banjarmasin State Polytechnic.

With the director's decree No.614/PL18/KL/2020 dated March 16, 2020, all activities that see crowds will be stopped and the entire teaching and learning process is carried out remotely or online using either a cell phone, PC, or laptop. The use of online media is considered very effective as a solution to prevent the spread of Covid-19 because it can be carried out face-to-face using video conferencing.

However, the implementation of online learning that has been going on for several weeks has generally been running smoothly. However, over time there have been many problems. Among them are courses that must be carried out practically because they are constrained by tools and materials to carry out practical work directly to complaints about quotas and internet networks. Even the complaints that are often raised by students through social media such as. " Sir, I am not afraid of the corona virus, but I am afraid if I have a concussion. Everyday tasks flow like a continuous flash flood. I want to go 
to school right away, Teacher," was a chain statement that appeared on social media during online lectures. It turns out that online learning that has been going on has caused many problems and these problems are not only experienced by students and teachers, even in the higher education institutions for students and lecturers.

Although there have been many complaints both at the student level or student level regarding online lectures, recently the results of research conducted [4] showed that students' perceptions of online learning revealed that it was good in the midst of the COVID-19 pandemic and they considered learning online is very helpful in the midst of a pandemic. Despite the positive perceptions of students regarding online learning. However, it should be remembered that learning in class is not always filled with assignments or working on a large number of questions. The teacher can give the task of observing, experimenting, and analyzing, making it more interesting and challenging.

One of the objectives of learning including online is the achievement of student competencies known as the $4 \mathrm{Cs}$, namely: (1) Critical thinking (critical thinking) which directs students to be able to solve problems (problem solving). (2) Creativity thinking means that teachers can assist students with high creativity who are able to think and see a problem from various sides or perspectives. (3) Collaboration (work together or collaborate). This activity is important to apply in the learning process so that students are able and ready to work together with anyone in their future lives. (4) Communication (communicating) can be interpreted as the ability of students to convey ideas and thoughts quickly, clearly, and effectively [5].

In the online learning process the use of cell phones is no longer just a means of communicating but can be used as a medium to access various information. The Covid-19 pandemic has changed the face-to-face pursuit system to become virtual, forcing everyone to apply virtual learning. However, not everyone is accustomed to using technology so that there are various obstacles in preparing the teaching and learning process. Even clear rules from the government regarding the use of online media, so that each teacher uses different online media, making it difficult for students.

For this reason, the success of online learning requires rules and synergistic cooperation between lecturers and students and policy makers. In addition, the success of online learning during this time of the COVID-19 crisis depends on using the right online media to use. Therefore, it is necessary for the relevant agencies to make schemes by compiling good management in regulating the online learning system.

This study aims to evaluate online learning in the Department of Accounting at the State Polytechnic of Banjarmasin, especially the computerized accounting study program so that effective online media can be used during the COVID-19 pandemic.

\section{MethodOLOGY}

The method used in this research is descriptive qualitative using google form to collect data [6]. The purpose of this study was to determine the effectiveness of online classes in the Banjarmasin State Polytechnic Accounting Department during the COVID-19 pandemic. The sample of this study was 119 DIV and DIII students who were in the even semester of the 2019-2020 school year. The criteria for assessment in this study are as follows:

\section{A. Characteristics of Respondents}

The research was conducted through an online of students majoring in accounting which consisted of three study programs, namely DIII A accounting, DIII Computerized Accounting and DIV Islamic Financial Institutions. The students who filled out this survey were students who took computer practice courses and were in semesters IV and VI. Survey conducted in August 2020. 81 students filled out a questionnaire on the total students as many as 119 people. Survey given through a google form with the share via WhatsApp group.

\section{B. Types of Learning Media}

The analysis was conducted divided into 4 media, namely (1.) online meeting consisting of google meet and zoom meeting (2.) The virtual learning environment (VLE) which consists of google classroom, Edmodo and Schoology (3.) learning videos using YouTube which are used to deliver learning materials (4.) The chat group consisting of consisting of WhatsApp group and telegrams group used for learning discussion.

\section{Interest in Using Online Learning Media}

To analyze how much influence the interest users of online learning media, namely (1) not at all interested, (2) lack of interest, (3) sufficient interest and (4.) very interested. This evaluation is carried out to see how much influence the interest in learning online with the type of online media used.

\section{Implementation of Learning}

Analysis of the implementation of learning was carried out to find out whether online learning during the Covid-19 pandemic was carried out properly (structured, on schedule, coordinated). The analysis was carried out by giving questions (1.) less (2.) sufficient, (3.) good and (4.) very good.

\section{E. Quality of Teaching Materials}

The analysis of teaching materials was carried out to determine the quality of the material provided by the teacher during online learning. The questions that were given to analyze the teaching materials were as follows: (1.) not of high quality, (2.) of less quality, (3) of sufficient quality and (4.) of high quality. 


\section{RESULT AND DISCUSSION}

Based on data obtained from the survey, the number of male respondents was 19 respondents (23\%) and female respondents were 62 respondents $(77 \%)$ of the total respondents who are half of the fourth as much 64 respondents (79\%) and students who are in sixth semester as much 17 respondents $(21 \%)$.

\section{A. A. Number of Respondents based on the Study \\ Program}

Based on the data obtained from respondents who filled out questionnaires of three courses that is as much as 39 respondents $(48 \%)$ come from accounting study program. While computerized accounting study program total of 27 respondents $(33 \%)$. While accounting for Islamic financial institutions many as 15 respondents (19\%). The results of respondent analysis based on the study program can be seen in Figure 1. Number of Study Program Respondents.

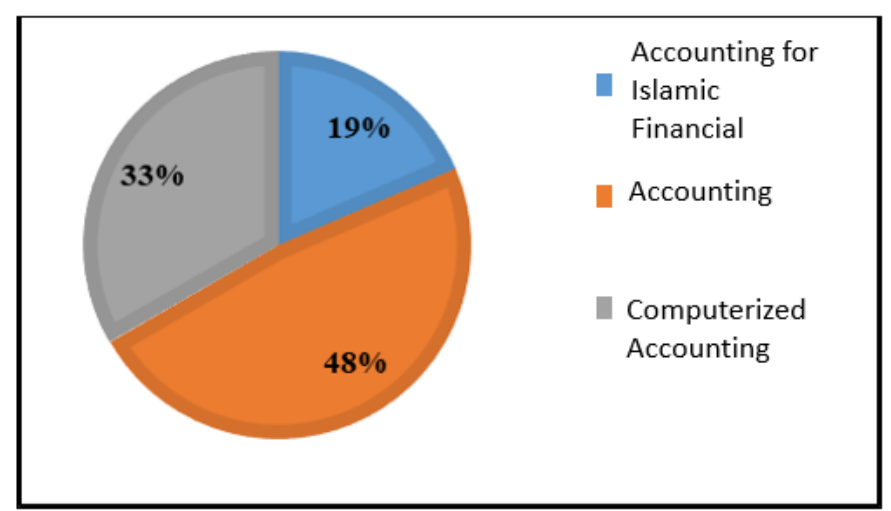

Fig. 1. Number of study program respondents.

\section{B. The type of Online Media used}

Based on the results of the analysis of the use of online media that are used for online learning survey results indicate that the students more like using instructional media-based online Virtual Learning Environment (VLE). Can be seen from the number of respondents who chose VLE-based learning as much as 31 respondents (38\%). While a student / i choose online meetings based learning media as much as 18 respondents $(22 \%)$. While students choosing based learning media group chat as much as 14 respondents $(18 \%)$ and students choosing media based instructional videos or youtube much as 9 respondents $(11 \%)$. On the other the students choosing all learning media are used as much as 9 respondents (11\%). The results of the analysis of respondents by type of online media that use can be seen in Figure 2. The Media Used Online Learning.

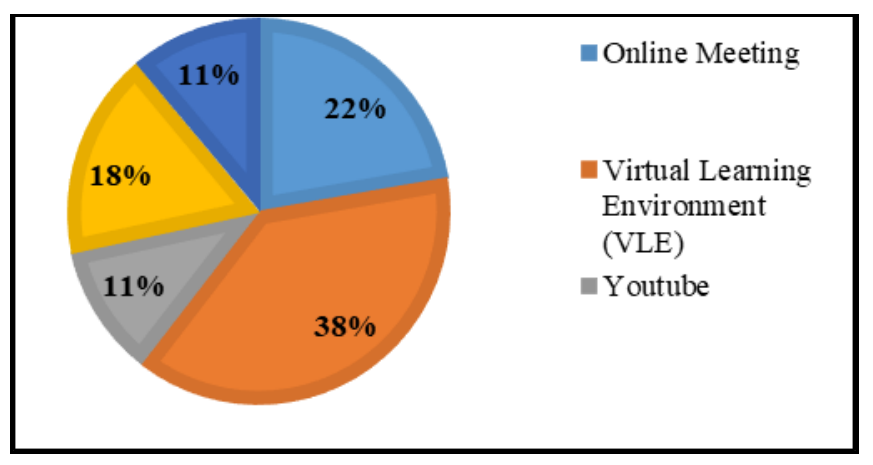

Fig. 2. The media used online learning.

\section{Interest in Online Learning}

Then this study analysis student interest when studying online. The result analysis shows that the student have interest in following the learning of conducted at the Department of Accounting. This can be seen from the survey results which showed 47 respondents (58\%) chose "quite interested". While a student choose "less interested" in online learning as much as 21 respondents (26\%). While students chose "very interested" in online learning as much as 14 respondents $(14 \%)$. On the other are student who chose "not at all interested" in online learning as much as 2 respondents (2\%). The results of the analysis of respondents based on Interest in online learning can be seen in Figure 3. Interest in Learning Online.

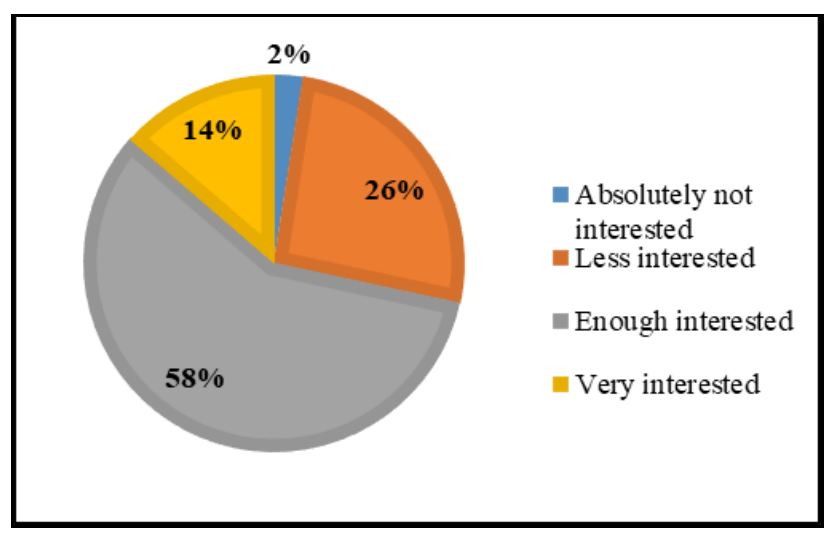

Fig. 3. Interest in learning online.

\section{Are all Learning Activities Carried out well (Structured, on Schedule, Coordinated)}

This research also analysis whether learning activities are carried out properly (structured, on schedule and coordinated). The survey results show that online learning conducted at the Banjarmasin State Polytechnic Accounting Department was carried out well or structured, on schedule and coordinated. It can be seen from the results of a survey completed by students counted 40 respondents (49\%) chose "enough". While a student choosing "good" by 28 respondents (35\%) and students who chose "excellent" by 2 respondents (2\%). On the other, there is the student voted "no good" by 11 respondents (14\%). The results of the respondent analysis based on the 
Implementation of Bold Learning can be found (Figure 4. Implementation of Bold Learning.

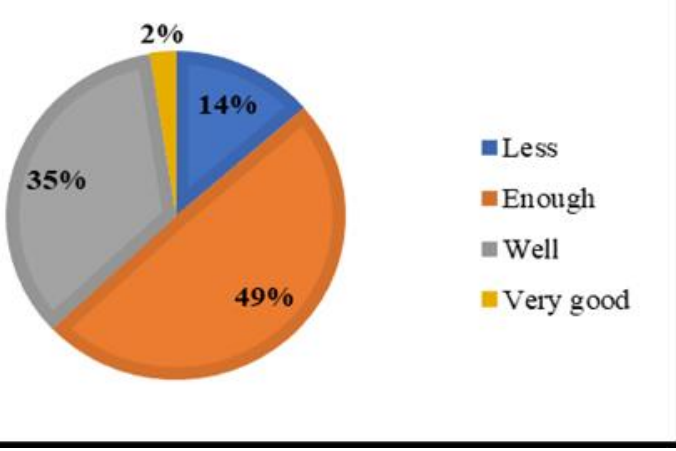

Fig. 4. Implementation of bold learning.

\section{E. Teaching materials Obtained during Online Learning}

This study also analyzes the teaching materials provided by the lecturers during the online learning is to meet Semester Lesson Plan (RPS) in the Accounting Department. The survey results show that learning in the Accounting Department has been implemented in accordance with the Semester Lesson Plan (RPS). It can be seen from the number of students that fill "enough quality" of 52 respondents $(64 \%)$ and student who chose "very quality" as much as 8 respondents (10\%). While students chose "lest quality" as many as 20 respondents $(25 \%)$ and students voted "not quality" as one respondent $(1 \%)$. The results of the respondent analysis based on Teaching Materials Obtained During Online Learning can be seen in Figure 5. Teaching Materials Obtained During Online Learning.

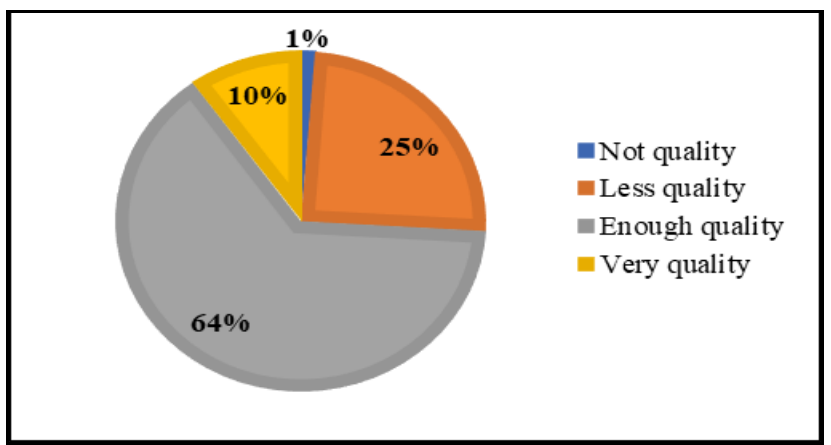

Fig. 5. Teaching materials obtained during online learning.

\section{CONCLUSIONS}

The results of this survey illustrate that the majority of the lectures online more like student with based virtual learning environment (VLE) followed online meetings and group chat. In addition, this study also found that not all students like to learn online, it can be seen from the $26 \%$ of respondents chose not interested in online learning.

This study also found that online learning during the Covid19 pandemic online learning carried out in the Banjarmasin State Polytechnic Accounting Department was carried out well or structured, on schedule and coordinated, this can be seen by the number of survey percentages $49 \%$ of respondents chose online learning to be carried out in an organized manner. structured, on schedule and coordinated.

Meanwhile, the teaching materials provided by the lecturer during online learning have fulfilled the Semester Learning Plan (RPS). This can be seen from the survey results showing that learning in the Accounting Department has been implemented in accordance with the Semester Lesson Plan (RPS) as many as $64 \%$ of respondents chose "enough quality".

\section{REFERENCES}

[1] Who Int, "Coronavirus disease (COVID-19) outbreak situation," WHO, 2020. https://www.who.int/emergencies/diseases/novel-coronavirus2019 (accessed May 29, 2020).

[2] C.-19 Indonesia, "COVID-19, Task Force for the Acceleration of Handling,” 2020. https://covid19.go.id/ (accessed May 28, 2020).

[3] Who.int, "Coronavirus disease (COVID-19) is an infectious disease caused by a newly discovered coronavirus.,"WHO, 2020. https://www.who.int/health-topics/coronavirus\#tab= tab_1 (accessed Sep. 29, 2020).

[4] M. Deli and G. Allo, "Is the online learning good in the midst of the Covid-19 Pandemic? The case of EFL learners," J. Synestesia, vol. 10, no. 1, pp. 1-10, 2020.

[5] Ditpsmk, "Strengthening 21st Century Learning with Vocational Education,"

2017

http://www.ditpsmk.net/index.php/konten/2828/menguatkanpembelajaran-abad-21-dengan-pend Pendidikan-vokasi (accessed May 29, 2020).

[6] R. Putri and O. R, "Evaluation the Efectiveness Online Class on Fudamental Biophysics Class During COVID 19 Quarantine," Semesta, vol. 3 , no. 1 , pp. $65-70,2020$. 